\title{
Variation in Septoria musiva and Implications for Disease Resistance Screening of Poplars
}

\author{
K. T. Ward and M. E. Ostry, North Central Research Station, 1561 Lindig Street, St. Paul, MN 55108
}

\begin{abstract}
Ward, K. T., and Ostry, M. E. 2005. Variation in Septoria musiva and implications for disease resistance screening of poplars. Plant Dis. 89:1077-1082.

A set of isolates of Septoria musiva differed in aggressiveness in hybrid poplar leaf disk and stem assays and culture growth in vitro. Clone $\times$ isolate interactions were observed in one of the stem assay experiments, but not in the leaf disk assay experiments. Random amplified polymorphic DNA (RAPD) analyses were performed using 52 isolates of $S$. musiva collected from hybrid poplars and a native poplar species in Minnesota, Wisconsin, Iowa, South Dakota, and North Dakota. There was a large degree of genetic similarity, although each isolate had a unique RAPD pattern. No relationships among isolates were found for molecular genetic distance and host clone, parentage, or taxonomic classification section; location or date of collection; or the previously determined level of field resistance of the host clones to Septoria canker. Results of the stem and leaf disk assays indicate that it may not be necessary to choose the most aggressive isolate for disease resistance screening. It may be more useful to select isolates that will discriminate the greatest variation in levels of disease resistance among the clones that are being screened.
\end{abstract}

Populus species and hybrids are ideally suited for production of fuel and fiber in intensive plantation culture due to their rapid early growth, ease of propagation, genetic diversity, and adaptability over a range of planting sites. However, a major problem restricting the use of many hybrid poplar clones is their susceptibility to leaf spot and canker diseases caused by Septoria musiva Peck (teleomorph: Mycosphaerella populorum Thompson).

In the northeastern and midwestern United States, S. musiva is one of the most damaging pathogens of hybrid poplars $(7,12)$, resulting in premature defoliation and multiple branch and stem cankers (9). In contrast, $S$. musiva is generally a leaf spot but not a canker pathogen on native eastern cottonwood ( $P$. deltoides) and balsam poplar ( $P$. balsamifera) in the eastern United States (9). Septoria populicola Peck (teleomorph: M. populicola Thompson) causes a leaf disease, but not stem cankers, on native black cottonwood $(P$. trichocarpa) and its hybrids in the Pacific Northwest, native balsam poplar in the eastern United States, and on native poplars in other parts of North America. To date, $S$. musiva has not been found in the

Corresponding author: K. T. Ward

E-mail: kward01@fs.fed.us

Accepted for publication 6 June 2005.

DOI: $10.1094 /$ PD-89-1077

This article is in the public domain and not copyrightable. It may be freely reprinted with customary crediting of the source. The American Phytopathological Society, 2005.
Pacific Northwest (8), which may explain the absence of Septoria canker in hybrid black cottonwood plantings in that region.

Isolates of $S$. musiva have been found to vary widely in aggressiveness (4,5), growth rate, color, morphology, and sporulation in culture (11). Krupinsky (4) found that there were differences in aggressiveness in glasshouse assays among isolates of S. musiva, not only from diverse locations (14 counties in 3 states), but also among those isolates from local sources.

The objective of the study was to gain information about $S$. musiva that would assist poplar growers and breeders in the Midwest to improve the effectiveness of their disease resistance screening programs. We assessed not only variability among isolates in aggressiveness on leaf and stem tissue, but also that of isolate growth in vitro, clone $\times$ isolate interactions, correlations between the results of the leaf disk, stem, and growth assays, and relationships between molecular genetic distance of isolates of S. musiva and host clones, collection locations and time, and levels of previously determined field canker resistance of the host clones.

\section{MATERIALS AND METHODS}

Origin and culture of isolates. A total of 1,049 isolates of $S$. musiva were obtained from 3- to 7-year-old hybrid poplar clones in biomass plantations and from native eastern cottonwood and balsam poplar in Iowa, Minnesota, North Dakota, South Dakota, and Wisconsin. Analyses were performed on a subset of 52 isolates of $S$. musiva representing collections from 48 hybrid poplar clones and four eastern cottonwood clones at 11 locations in five states (Table 1).

Collections in plantations were made from a set of poplar clones resistant and susceptible to Septoria leaf spot and canker (7). Approximately 20 fully developed leaves of similar age infected with $S$. musiva were collected at plantations from poplar clones within 16-tree blocks. To investigate the temporal variability within S. musiva, collections were made in 2 years (1992 and 1993) at two locations (Milaca, MN, and Mondovi, WI). Infected leaves from Eastern cottonwood and balsam poplar were collected from natural stands adjacent to selected hybrid poplar plantations. Leaves were stored in plastic bags in a cooler until isolations were made. Infected leaf tissue was cut into $2 \mathrm{~mm}^{2}$ sections, soaked in a $0.05 \%$ sodium hypochlorite solution for 30 to $45 \mathrm{~s}$, rinsed in sterile, deionized, distilled water, and placed onto potato dextrose agar in petri dishes at $20^{\circ} \mathrm{C}$ in the light. Successfully recovered cultures were maintained on $\mathrm{V} 8$ juice agar (18\% V8 juice, $2 \%$ agar, and $2 \mathrm{~g}$ of calcium carbonate per liter) at $20^{\circ} \mathrm{C}$ and were illuminated under continuous coolwhite fluorescent light at 3,000 lux.

Stem canker assay. Five isolates of $S$. musiva were selected for the stem assay (Table 1). Two of the isolates (isolates 41 and 42) were collected from the same host clone and location in 1993; the others were from different host clones and locations, and were collected in 1992 and 1993. Five poplar clones varying in susceptibility to Septoria canker were chosen for the assay based on their previously determined differences in field resistance to infection by S. musiva (7) (Table 2). The clones were vegetatively propagated from hardwood cuttings and rooted on a mist bench. The rooted clones were grown in the greenhouse ( 18 to $30^{\circ} \mathrm{C}, 18$-h photoperiod) in a 3:1:1 mixture of peat:perlite:vermiculite in $36 \mathrm{~cm}$ deep $\times 10 \mathrm{~cm}$ diameter, $230 \mathrm{~cm}^{3}$ capacity plastic pots. Sets contained one of each of the five clones. A total of 40 sets containing a total of 173 trees were assayed: 20 sets containing 87 trees in the first experiment and 20 sets containing 86 trees in the second. Not all sets had a full complement of five clones due to the failure of some cuttings to root, especially clone DN2. Inoculations were made using one of the five isolates on the trees of each set. There were three inoculation positions per tree: near the top, middle, and bottom of the crown. At each position, a petiole 
was removed and the inoculum was applied. At two of the positions, a $1 \mathrm{~mm}^{2}$ piece of a sporulating culture grown on $\mathrm{V} 8$ juice agar was placed on the petiole scar. At the third position, a $1 \mathrm{~mm}^{2}$ piece of sterile V8 juice agar was applied as a control. Positions for the three inoculations were randomly assigned per tree. The area was sealed after inoculation with Parafilm M (Pechiney Plastic Packaging, Chicago, IL). The Parafilm was removed 2 weeks after inoculation.

Canker lengths and widths were measured three times at 2-week intervals after the inoculations and canker areas were computed from the measurements. Pairwise compari- sons of canker means among isolates and among clones were completed using ANOVA, Fisher's LSD, and the software package SAS (SAS Institute Inc., Cary, NC).
In vitro leaf disk assay. Leaves from the same five poplar clones as above (Table 2) were screened with the same five isolates (Table 1) using a leaf disk tech-

Table 2. Parentage and level of field resistance to Septoria stem canker of poplar clones used in the leaf disk and stem canker assays and in vitro growth assays

\begin{tabular}{llc}
\hline Clone & Parentage & $\begin{array}{c}\text { Field resistance } \\
\text { to Septoria canker }\end{array}$ \\
\hline DN34 & Populus deltoides $\times$ P. nigra cv. Eugenei & High \\
DN2 & P. deltoides $\times$ P. nigra cv. Baden & Medium \\
DN182 & P. deltoides $\times$ P. nigra cv. Raverdeau & Medium \\
Jackii4 & $P$. balsamifera $\times$ P. deltoides & Low \\
NE299 & $P$. nigra var. betulifolia $\times$ P. trichocarpa & Low \\
\hline
\end{tabular}

${ }^{\mathrm{z}}$ Field disease resistance previously reported by Netzer and others (7).

Table 1. Isolate code; hybrid poplar clone, parentage, and taxonomic classification section; and geographic location, month, and year of collection of isolates of Septoria musiva

\begin{tabular}{|c|c|c|c|c|c|}
\hline Isolate $^{\mathrm{y}}$ & Clone & Parentage & Section $^{\mathrm{z}}$ & Location & Date \\
\hline 1 & JACKII 4 & Populus balsamifera $\times P$. deltoides & $\mathrm{T} \times \mathrm{A}$ & Granite Falls, MN & Aug 91 \\
\hline 2 & Hybrid poplar & $\mathrm{n} / \mathrm{a}$ & $\mathrm{n} / \mathrm{a}$ & Ames, IA & $\mathrm{n} / \mathrm{a} 91$ \\
\hline 3 & JACKII 4 & $P$. balsamifera $\times P$. deltoides & $\mathrm{T} \times \mathrm{A}$ & Milaca, MN & Jun 92 \\
\hline 4 & DN 34 & $P$. deltoides $\times P$. nigra & $\mathrm{A} \times \mathrm{A}$ & Granite Falls, MN & Sept 92 \\
\hline 5 & Siouxland & $P$. deltoides $\times P$. nigra & $\mathrm{A} \times \mathrm{A}$ & Granite Falls, MN & Sept 92 \\
\hline 6 & DN 182 & $P$. deltoides $\times P$. nigra & $\mathrm{A} \times \mathrm{A}$ & Granite Falls, MN & Sept 92 \\
\hline 7 & NE 242 & $P$. deltoides $\times P$. nigra var. plantierensis & $\mathrm{A} \times \mathrm{A}$ & Milaca, MN & Jun 92 \\
\hline $8^{*}$ & DTAC 26 & $P$. deltoides $\times P$. trichocarpa & $\mathrm{A} \times \mathrm{T}$ & Rhinelander, WI & Sept 92 \\
\hline 9 & NM 6 & $P$. nigra $\times P$. maximowiczii & $\mathrm{A} \times \mathrm{T}$ & Ashland, WI & Sept 92 \\
\hline 10 & NM 2 & $P$. nigra $\times P$. maximowiczii & $\mathrm{A} \times \mathrm{T}$ & Ashland, WI & Sept 92 \\
\hline 11 & NM 6 & $P$. nigra $\times P$. maximowiczii & $\mathrm{A} \times \mathrm{T}$ & Rhinelander, WI & Sept 92 \\
\hline 12 & NM 2 & $P$. nigra $\times P$. maximowiczii & $\mathrm{A} \times \mathrm{T}$ & Rhinelander, WI & Sept 92 \\
\hline 13 & NE 299 & P. nigra var. betulifolia $\times P$. trichocarpa & $\mathrm{A} \times \mathrm{T}$ & Rhinelander, WI & Oct 92 \\
\hline 14 & NE 299 & P. nigra var. betulifolia $\times P$. trichocarpa & $\mathrm{A} \times \mathrm{T}$ & Rhinelander, WI & Oct 92 \\
\hline 15 & NE 308 & $P$. nigra var. charkowiensis $\times P$. nigra $\mathrm{cv}$. incrassata & $\mathrm{A} \times \mathrm{A}$ & Granite Falls, MN & Sept 92 \\
\hline 16 & NE 308 & $P$. nigra var. charkowiensis $\times P$. nigra $\mathrm{cv}$. incrassata & $\mathrm{A} \times \mathrm{A}$ & Milaca, MN & Sept 92 \\
\hline $17 *$ & NE 28 & P. nigra var. charkowiensis $\times P$. trichocarpa & $\mathrm{A} \times \mathrm{T}$ & Cloquet, $\mathrm{MN}$ & Sept 92 \\
\hline 18 & NE 28 & P. nigra var. charkowiensis $\times P$. trichocarpa & $\mathrm{A} \times \mathrm{T}$ & Milaca, MN & Jun 92 \\
\hline 19 & NC 5260 & $P$. tristis $\times P$. balsamifera & $\mathrm{T} \times \mathrm{T}$ & Rhinelander, WI & Sept 92 \\
\hline 20 & JACKII 4 & $P$. balsamifera $\times P$. deltoides & $\mathrm{T} \times \mathrm{A}$ & Milaca, MN & Sept 93 \\
\hline 21 & NE 54 & P. candicans $\times P . \times$ berolinensis & $\mathrm{T} \times \mathrm{T} \times \mathrm{A}$ & Mondovi, WI & Sept 93 \\
\hline 22 & NE 54 & P. candicans $\times P . \times$ berolinensis & $\mathrm{T} \times \mathrm{T} \times \mathrm{A}$ & Mondovi, WI & Sept 93 \\
\hline 23 & Cottonwood & P. deltoides & $\mathrm{A} \times \mathrm{A}$ & Fargo, ND & Sept 93 \\
\hline 24 & Cottonwood & P. deltoides & $\mathrm{A} \times \mathrm{A}$ & Rosemount, MN & Aug 93 \\
\hline 25 & Cottonwood & P. deltoides & $\mathrm{A} \times \mathrm{A}$ & Rosemount, MN & Aug 93 \\
\hline 26 & Cottonwood & P. deltoides & $\mathrm{A} \times \mathrm{A}$ & Rosemount, MN & Aug 93 \\
\hline 27 & DN 74 & $P$. deltoides $\times P$. nigra & $\mathrm{A} \times \mathrm{A}$ & Fargo, ND & Sept 93 \\
\hline 28 & DN 70 & $P$. deltoides $\times P$. nigra & $\mathrm{A} \times \mathrm{A}$ & Granite Falls, MN & Sept 93 \\
\hline 29 & DN 70 & $P$. deltoides $\times P$. nigra & $\mathrm{A} \times \mathrm{A}$ & Granite Falls, MN & Sept 93 \\
\hline 30 & DN 70 & $P$. deltoides $\times P$. nigra & $\mathrm{A} \times \mathrm{A}$ & Granite Falls, MN & Sept 93 \\
\hline 31 & I $45 / 51$ & $P$. deltoides $\times P$. nigra & $\mathrm{A} \times \mathrm{A}$ & Milaca, MN & Sept 93 \\
\hline 32 & DN 34 & $P$. deltoides $\times P$. nigra & $\mathrm{A} \times \mathrm{A}$ & Sioux Falls, SD & Sept 93 \\
\hline 33 & DN 34 & $P$. deltoides $\times P$. nigra & $\mathrm{A} \times \mathrm{A}$ & Sioux Falls, SD & Sept 93 \\
\hline 34 & NE 351 & $P$. deltoides $\times P$. nigra var. caudina & $\mathrm{A} \times \mathrm{A}$ & Milaca, MN & Jul 93 \\
\hline 35 & NE 351 & $P$. deltoides $\times P$. nigra var. caudina & $\mathrm{A} \times \mathrm{A}$ & Mondovi, WI & Sept 93 \\
\hline 36 & NE 351 & $P$. deltoides $\times P$. nigra var. caudina & $\mathrm{A} \times \mathrm{A}$ & Rhinelander, WI & Sept 93 \\
\hline 37 & NE 242 & $P$. deltoides $\times P$. nigra var. plantierensis & $\mathrm{A} \times \mathrm{A}$ & Mondovi, WI & Jul 93 \\
\hline 38 & NE 242 & $P$. deltoides $\times P$. nigra var. plantierensis & $\mathrm{A} \times \mathrm{A}$ & Mondovi, WI & Sept 93 \\
\hline 39 & DTAC 7 & $P$. deltoides $\times P$. trichocarpa & $\mathrm{A} \times \mathrm{T}$ & Fairmont, MN & Sept 93 \\
\hline 40 & DTAC 26 & $P$. deltoides $\times P$. trichocarpa & $\mathrm{A} \times \mathrm{T}$ & Milaca, MN & Sept 93 \\
\hline $41 *$ & NE 252 & $P$. deltoides var. angulata $\times P$. trichocarpa & $\mathrm{A} \times \mathrm{T}$ & Ashland, WI & Sept 93 \\
\hline $42 *$ & NE 252 & $P$. deltoides var. angulata $\times P$. trichocarpa & $\mathrm{A} \times \mathrm{T}$ & Ashland, WI & Sept 93 \\
\hline 43 & NE 252 & $P$. deltoides var. angulata $\times P$. trichocarpa & $\mathrm{A} \times \mathrm{T}$ & Ashland, WI & Sept 93 \\
\hline 44 & NE 51 & P. maximowiczii $\times P . \times$ beroliniensis & $\mathrm{T} \times \mathrm{A}$ & Milaca, MN & Aug 93 \\
\hline 45 & NE 299 & P. nigra var. betulifolia $\times P$. trichocarpa & $\mathrm{A} \times \mathrm{T}$ & Milaca, MN & Sept 93 \\
\hline 46 & NE 299 & P. nigra var. betulifolia $\times P$. trichocarpa & $\mathrm{A} \times \mathrm{T}$ & Milaca, MN & Sept 93 \\
\hline 47 & NE 299 & P. nigra var. betulifolia $\times P$. trichocarpa & $\mathrm{A} \times \mathrm{T}$ & Mondovi, WI & Jul 93 \\
\hline 48 & NE 299 & P. nigra var. betulifolia $\times P$. trichocarpa & $\mathrm{A} \times \mathrm{T}$ & Rhinelander, WI & Sept 93 \\
\hline 49 & NE 17 & P. nigra var. charkowiensis $\times P$. nigra var. caudina & $\mathrm{A} \times \mathrm{A}$ & Rosemount, MN & Sept 93 \\
\hline $50 *$ & DIPL & $P$. tremuloides $\times P$. tremula & $\mathrm{P} \times \mathrm{P}$ & Milaca, MN & Sept 93 \\
\hline 51 & NC 5260 & P. tristis $\times P$. balsamifera & $\mathrm{T} \times \mathrm{T}$ & Ashland, WI & Sept 93 \\
\hline 52 & NC 5260 & $P$. tristis $\times P$. balsamifera & $\mathrm{T} \times \mathrm{T}$ & Fargo, ND & Sept 93 \\
\hline
\end{tabular}

y Codes followed by an asterisk are isolates of $S$. musiva that were used in leaf disk, stem canker, and in vitro growth assays.

${ }^{z}$ Populus taxonomic classification section: A, Aegiros; P, Populus; T, Tacamahaca. 
nique (10). Conidia were removed from 7to 10-day-old cultures of isolates of $S$. musiva by flooding the plates with distilled, deionized water and gently agitating the plates. The conidial suspension was adjusted to a concentration of $1 \times 10^{6}$ conidia per $\mathrm{ml}$ by serial dilutions and use of a hemacytometer. Each leaf disk was inoculated with $0.1 \mathrm{ml}$ of the conidial suspension. Distilled deionized water was applied to leaf disks that served as controls. Eighteen leaf disks from each of the five clones were inoculated with one of each of the five isolates, and the experiment was repeated once. There were a total of 450 leaf disks screened in each of the two experiments. Six leaf disks per clone per isolate served as uninoculated controls in each experiment; 150 leaf disks in each of the two experiments. Leaf disks were incubated in continuous light (20 to $25^{\circ} \mathrm{C}$; 2,000 lux).

Leaf necrosis was measured beginning the fourth day after inoculation by overlaying a dot grid $\left(25\right.$ dots per $1.8 \mathrm{~cm}^{3}$ leaf disk) and counting the number of dots that coincided with necrotic tissue on each of the leaf disks. Measurements were made every 4 days and continued for 32 days. Measurements from both experiments were pooled for analysis. Pairwise comparisons of necrotic area means among isolates and among clones were completed using ANOVA, Fisher's LSD, and the software package SAS (SAS Institute).

In vitro culture growth assay. The five isolates that were used in the stem and leaf disk assays (Table 1) were assessed for differences in growth in laboratory assays. Plugs were removed from actively growing cultures using a no. 5 cork borer sterilized with heat and $70 \%$ ETOH. The plugs were placed onto $\mathrm{V} 8$ juice media in petri dishes. The cultures were grown in a lighted incubator at $20^{\circ} \mathrm{C}$ at 2,000 lux for 21 days. The area of colony growth was calculated from measurements of the length and width of the cultures. There were five cultures of each isolate per assay, and the experiment was repeated once. Pairwise comparisons of growth means among isolates were completed using ANOVA, Fisher's LSD, and the software package SAS (SAS Institute).

Comparisons in assay means among isolates and among clones. Correlation matrices were calculated using the area means from the stem, leaf disk, and in vitro culture growth assays, the Corr procedure, and the software package SAS (SAS Institute).

Random amplified polymorphic DNA (RAPD) analyses. Isolates were grown in a Liquid Medium II denoted by Griffin et al. (3) (28 mM glucose, $2 \mathrm{mM} \mathrm{MgSO} 4,0.9$ $\mathrm{mM} \mathrm{CaCl}, 10 \mathrm{mM} \mathrm{KH_{2 }} \mathrm{PO}_{4}, 11 \mu \mathrm{M}$ $\mathrm{H}_{3} \mathrm{BO}_{3}, 0.69 \mu \mathrm{M} \mathrm{CoCl} \mathrm{Cl}_{2} \cdot 6 \mathrm{H}_{2} \mathrm{O}, 0.32 \mu \mathrm{M}$ $\mathrm{CuSO}_{4} \cdot 5 \mathrm{H}_{2} \mathrm{O}, \quad 1.8 \mu \mathrm{M} \quad \mathrm{MnCl}_{2} \cdot 4 \mathrm{H}_{2} \mathrm{O}$, $0.41 \mu \mathrm{M} \quad \mathrm{Na}_{2} \mathrm{MoO}_{4} \cdot 2 \mathrm{H}_{2} \mathrm{O}, \quad 0.36 \mu \mathrm{M}$ $\mathrm{ZnSO}_{4} \cdot 7 \mathrm{H}_{2} \mathrm{O}, 0.3 \mu \mathrm{M}$ thiamin, $0.04 \mu \mathrm{M}$ biotin, and $2.5 \mathrm{~g} /$ liter casein enzymatic hydrolysate) at $26^{\circ} \mathrm{C}$ and in ambient light on an orbital shaker at 1,000 rpm. After 7 days of growth, mycelium was harvested on filter paper in a Buchner funnel under vacuum pressure. DNA was extracted using a microwave miniprep technique (2) and resuspended in 50 to $150 \mu$ l of TE buffer (10 mM Tris-HCl, $1 \mathrm{mM}$ EDTA, $\mathrm{pH}$ 8.0), depending on the size of the pellet. The concentration of DNA in each sample was quantified using a Hoefer fluorometer (Hoefer Scientific Instruments, San Francisco, CA), and each sample was adjusted to a concentration of $1 \mathrm{ng} / \mu \mathrm{l}$ DNA in sterile, deionized, distilled water.

RAPD analyses were performed using polymerase chain reaction (PCR) and the isolate DNA. PCRs were conducted in a $15-\mu l$ volume with final concentrations of $2.5 \mathrm{ng}$ of fungal DNA, $1 \times$ PCR buffer (Life Technologies, Grand Island, NY), $0.25 \mathrm{mM}$ of each dNTP (Perkin-Elmer, Norwalk, CT), $0.01 \mathrm{mg} / \mu \mathrm{l} 10 \times$ bovine serum albumin (Promega, Madison, WI), $30 \mathrm{mM} \mathrm{MgCl} 2$ (Life Technologies), 2.5 units Taq DNA polymerase (Life Technologies), and $1.2 \mathrm{mM}$ decamer primer (Operon Technologies, Alameda, CA). A total of 20 primers (OPF-01 through OPF20) were used. However, data are presented only for the five primers that allowed analyses of the largest group of common isolates. The primers were OPF02 (5'-GAGGATCCCT-3'), OPF-09 (5'CCAAGCTTCC-3'), OPF-10 (5'-GGAAGCTTGG-3'), OPF-15 (5'-CCAGTASM17C-3'), and OPF-20 (5'-GGTCTAGAGG-3'). PCRs were conducted in 96well plates (Hybaid, Ltd., Teddington, Middlesex, UK), and each well was overlaid with $25 \mu \mathrm{l}$ of mineral oil to prevent evaporation. Samples were amplified in a Hybaid Omnigene Thermal Cycler (Hybaid, Ltd.) with parameters of one cycle of $1.5 \mathrm{~min}$ at $94.5^{\circ} \mathrm{C}$, followed by 45 cycles of $1.5 \mathrm{~min}$ at $92.5^{\circ} \mathrm{C}, 2 \mathrm{~min}$ at $36^{\circ} \mathrm{C}$, and 2 min at $72^{\circ} \mathrm{C}$, and then maintained at $20^{\circ} \mathrm{C}$ prior to analysis. After amplification, $3 \mu \mathrm{l}$ of $6 \times$ loading buffer was added to each well. Samples were subjected to electrophoresis in $1.4 \%$ agarose gels in TAE (40 $\mathrm{mM}$ Trizma base, $0.1 \%$ glacial acetic acid, $2 \mathrm{mM} \mathrm{Na}{ }_{2}$ EDTA $2 \mathrm{H}_{2} \mathrm{O}, \mathrm{pH}$ 8.0) in a Gibco BRL (Invitrogen, Carlsbad, CA) horizontal

Table 4. Across-clone and across-isolate mean necrotic leaf tissue area of five poplar clones 32 days after inoculation of leaf disks with five isolates of Septoria musiva

\begin{tabular}{lcclcc}
\hline Isolate & $\begin{array}{c}\text { Disks } \\
(\text { no. })\end{array}$ & $\begin{array}{c}\text { Across-clone } \\
\text { mean }(\%)\end{array}$ & Clone & $\begin{array}{c}\text { Disks } \\
(\text { no. })\end{array}$ & $\begin{array}{c}\text { Across-isolate } \\
\text { mean }(\%)\end{array}$ \\
\hline 8 & 180 & $75.7 \mathrm{a}^{\mathrm{z}}$ & NE299 & 180 & $89.5 \mathrm{a}$ \\
17 & 180 & $69.1 \mathrm{~b}$ & Jackii & 180 & $74.1 \mathrm{~b}$ \\
50 & 180 & $66.7 \mathrm{~b}$ & DN2 & 180 & $61.3 \mathrm{c}$ \\
41 & 180 & $58.3 \mathrm{c}$ & DN182 & 180 & $58.2 \mathrm{c}$ \\
42 & 180 & $49.5 \mathrm{~d}$ & DN34 & 180 & $36.1 \mathrm{~d}$ \\
\hline
\end{tabular}

${ }^{\mathrm{z}}$ Pairwise comparisons of across-clone and across-isolate means were computed using ANOVA and Fisher's LSD. Means followed by the same letter were not significantly different at $P \geq 0.05$.

Table 3. Across-clone and across-isolate length, width, and area means of stem cankers on five poplar clones inoculated with five isolates of Septoria musiva

\begin{tabular}{|c|c|c|c|c|c|c|c|c|c|}
\hline \multicolumn{5}{|c|}{ Across-clone } & \multicolumn{5}{|c|}{ Across-isolate } \\
\hline Isolate & $\begin{array}{l}\text { Trees } \\
\text { (no.) }\end{array}$ & $\begin{array}{c}\text { Length } \\
(\mathrm{mm})\end{array}$ & $\begin{array}{l}\text { Width } \\
\text { (mm) }\end{array}$ & $\begin{array}{c}\text { Area } \\
\left(\mathbf{m m}^{2}\right)\end{array}$ & Clone & $\begin{array}{l}\text { Trees } \\
\text { (no.) }\end{array}$ & $\begin{array}{c}\text { Length } \\
(\mathrm{mm})\end{array}$ & $\begin{array}{l}\text { Width } \\
\text { (mm) }\end{array}$ & $\begin{array}{c}\text { Area } \\
\left(\mathbf{m m}^{2}\right)\end{array}$ \\
\hline \multicolumn{10}{|c|}{ Experiment 1} \\
\hline 17 & 33 & $26.6 \mathrm{a}^{\mathrm{z}}$ & $18.1 \mathrm{a}$ & $512.6 \mathrm{a}$ & Jackii4 & 40 & $32.9 \mathrm{a}$ & $21.1 \mathrm{a}$ & $707.9 \mathrm{a}$ \\
\hline 8 & 35 & $23.4 \mathrm{ab}$ & $15.8 \mathrm{a}$ & $424.8 \mathrm{a}$ & NE299 & 38 & $27.6 \mathrm{~b}$ & $18.8 \mathrm{a}$ & $545.9 \mathrm{~b}$ \\
\hline 50 & 36 & $22.8 \mathrm{ab}$ & $16.8 \mathrm{a}$ & $441.3 \mathrm{a}$ & DN182 & 40 & $21.7 \mathrm{c}$ & $18.7 \mathrm{a}$ & $423.4 \mathrm{bc}$ \\
\hline 41 & 38 & $25.5 \mathrm{ab}$ & $18.7 \mathrm{a}$ & $493.7 \mathrm{a}$ & DN2 & 20 & $18.1 \mathrm{~cd}$ & $14.8 \mathrm{~b}$ & $306.5 \mathrm{~cd}$ \\
\hline 42 & 32 & $21.7 \mathrm{~b}$ & $18.6 \mathrm{a}$ & $438.8 \mathrm{a}$ & DN34 & 36 & $16.1 \mathrm{~d}$ & $12.8 \mathrm{~b}$ & $231.9 \mathrm{~d}$ \\
\hline \multicolumn{10}{|c|}{ Experiment 2} \\
\hline 17 & 34 & $18.0 \mathrm{ab}$ & $13.2 \mathrm{a}$ & $270.1 \mathrm{a}$ & Jackii4 & 40 & $20.1 \mathrm{a}$ & $15.5 \mathrm{ab}$ & $369.2 \mathrm{a}$ \\
\hline 8 & 36 & $17.3 \mathrm{a}$ & $13.7 \mathrm{a}$ & $273.0 \mathrm{a}$ & NE299 & 40 & $22.7 \mathrm{a}$ & $16.1 \mathrm{a}$ & $414.1 \mathrm{a}$ \\
\hline 50 & 32 & $16.8 \mathrm{a}$ & $13.6 \mathrm{a}$ & $299.3 \mathrm{a}$ & DN182 & 28 & $22.9 \mathrm{a}$ & $16.3 \mathrm{a}$ & $404.7 \mathrm{a}$ \\
\hline 41 & 34 & $18.1 \mathrm{ab}$ & $13.7 \mathrm{a}$ & $315.2 \mathrm{a}$ & DN2 & 24 & $10.7 \mathrm{~b}$ & $9.8 \mathrm{~b}$ & $154.2 \mathrm{~b}$ \\
\hline 42 & 36 & $21.3 \mathrm{~b}$ & $17.3 \mathrm{~b}$ & $438.5 \mathrm{~b}$ & DN34 & 40 & $13.7 \mathrm{~b}$ & $12.7 \mathrm{~b}$ & $218.2 \mathrm{~b}$ \\
\hline
\end{tabular}

z Pairwise comparisons of across-clone and across-isolate means were computed using ANOVA and Fisher's LSD. Means followed by the same letter were not significantly different at $P \geq 0.05$. 
gel apparatus (37-cm length). As a molecular weight standard, $1.5 \mu \mathrm{g}$ of a $1-\mathrm{kb}$ DNA ladder (Life Technologies) was loaded in two lanes on each gel. Gels were stained with ethidium bromide and fragments were visualized on an ultraviolet light transilluminator. All isolates were amplified and assayed twice to check for repeatability. To test for repeatability over DNA extractions, a subsample of isolates underwent a second extraction, amplification, and assay. Unrepeatable or weakly amplified products were not included in the analyses.

Bands were scored as 1 representing band presence and 0 representing absence. Genetic diversity, $h$, for each marker was estimated as $h=2 p q$, where $p=$ frequency of individuals with the band present, and $q$ $=$ frequency of individuals with the band absent (6). The mean genetic diversity of all markers $=H(6)$. Phenetic analysis of the data was done using pairwise comparisons and simple matching, Jaccard and Dice coefficients, the neighbor-joining method, and the software package PAUP (Sinauer Associates Inc., Sunderland, MA) to create a similarity matrix. Relationships of the molecular genetic distance of isolates of S. musiva and host clones (hybrid poplar clone, parentage, and taxonomic classification section), collection locations (city and state), time of collection (month and year) (Table 1), and levels of previously determined field canker resistance of the host clones (7) were analyzed using linear regression and the software package Arc (University of Minnesota, St. Paul/Minneapolis, MN).

\section{RESULTS}

Stem canker assay. Experiments were analyzed separately, as the results were significantly different $(P<0.001)$. Due to greenhouse environmental and/or other unknown factors, all across-clone and almost all across-isolate stem canker means were smaller in experiment 2 compared with experiment 1 (Table 3 ). Inoculation with isolate 17 caused significantly greater mean across-clone canker length than those with isolate 42 in experiment 1 (Table 3). However, in experiment 2, inoculation with isolate 17 resulted in smaller mean canker length than isolate 42

Table 5. Mean growth in vitro of five isolates of Septoria musiva 21 days after inoculation onto plates containing V8 juice media

\begin{tabular}{lcc}
\hline Isolate & $\begin{array}{c}\text { Plates } \\
(\text { no. })\end{array}$ & $\begin{array}{c}\text { Area } \\
\left(\mathbf{m m}^{\mathbf{2}}\right)\end{array}$ \\
\hline 17 & 9 & $1,333.1 \mathrm{a}^{\mathrm{z}}$ \\
50 & 10 & $1,121.8 \mathrm{ab}$ \\
42 & 10 & $1,051.3 \mathrm{ab}$ \\
41 & 10 & $996.4 \mathrm{~b}$ \\
8 & 10 & $972.3 \mathrm{~b}$ \\
\hline
\end{tabular}

${ }^{\mathrm{z}}$ Pairwise comparisons of means were computed using ANOVA and Fisher's LSD. Means followed by the same letter were not significantly different at $P \geq 0.05$.
(Table 3). This may be in part because mean canker length on clone Jackii4 caused by inoculation with isolate 17 in experiment $2(20.6 \mathrm{~mm})$ was almost half that of mean canker length in experiment 1 $(35.7 \mathrm{~mm})$. Clone Jackii4 showed a similar decrease in mean canker length from experiment 1 to experiment 2 when inoculated with isolates 8 and 50 (data not shown). Mean across-clone canker widths and areas were similar in experiment 1 (Table 3). However, in experiment 2, inoculation with isolate 42 caused greater mean across-clone canker width and area than all other isolates (Table 3).

Levels of disease resistance among clones were similar to those previously found in the field (Table 2). Generally, mean across-isolate canker dimensions in both experiments were smaller on DN34, DN2, and DN182 than on NE299 and Jackii4 (Table 3). Significant clone $\times$ isolate interactions were not detected in experiment 1 for canker length $(P=0.745)$, width $(P=0.584)$, or area $(P=0.548)$. However, significant clone $\times$ isolate interactions were observed in experiment 2 for canker length $(P=0.010)$, width $(P=$ $0.003)$, and area $(P=0.002)$.

In vitro leaf disk assay. Inoculation with isolate 8 resulted in the largest necrotic leaf area, and inoculation with isolate 42 the smallest necrotic leaf area (Table 4). Mean necrotic leaf area was similar for isolates 17 and 50 (Table 4).

Levels of disease resistance among clones were similar to those previously found in the field (Table 2). Mean necrotic

Table 6. Correlation matrix of means of isolates of Septoria musiva in the leaf, stem, and in vitro growth assays

\begin{tabular}{lcccc}
\hline & \multicolumn{3}{c}{ Assay $^{\mathbf{c}}$} \\
\cline { 2 - 5 } Assay & Stem exp. 1 & Stem exp. 2 & Leaf & Growth in vitro \\
\hline Stem exp. 1 & 1.000 & -0.305 & -0.049 & 0.625 \\
Stem exp. 2 & -0.305 & 1.000 & -0.907 & -0.283 \\
Leaf & -0.049 & -0.907 & 1.000 & 0.178 \\
Growth in vitro & 0.625 & -0.283 & 0.178 & 1.000 \\
\hline
\end{tabular}

${ }^{\mathrm{z}}$ Mean canker area $\left(\mathrm{mm}^{2}\right)$ in stem assay, mean necrotic area $(\%)$ in leaf assay, and mean area $\left(\mathrm{mm}^{2}\right)$ in growth assay for each of the five isolates in the assays.

Table 7. Correlation matrix of means of poplar clones in the leaf and stem assays

\begin{tabular}{lccc}
\hline & \multicolumn{3}{c}{ Assay $^{\mathbf{z}}$} \\
\cline { 2 - 4 } Assay & Stem exp. 1 & Stem exp. 2 & Leaf disk \\
\hline Stem exp. 1 & 1.000 & 0.725 & 0.775 \\
Stem exp. 2 & 0.725 & 1.000 & 0.606 \\
Leaf & 0.775 & 0.606 & 1.000 \\
\hline
\end{tabular}

${ }^{\mathrm{z}}$ Mean canker area $\left(\mathrm{mm}^{2}\right)$ in stem assay and mean necrotic area (\%) in leaf disk assay for each of the five clones screened.

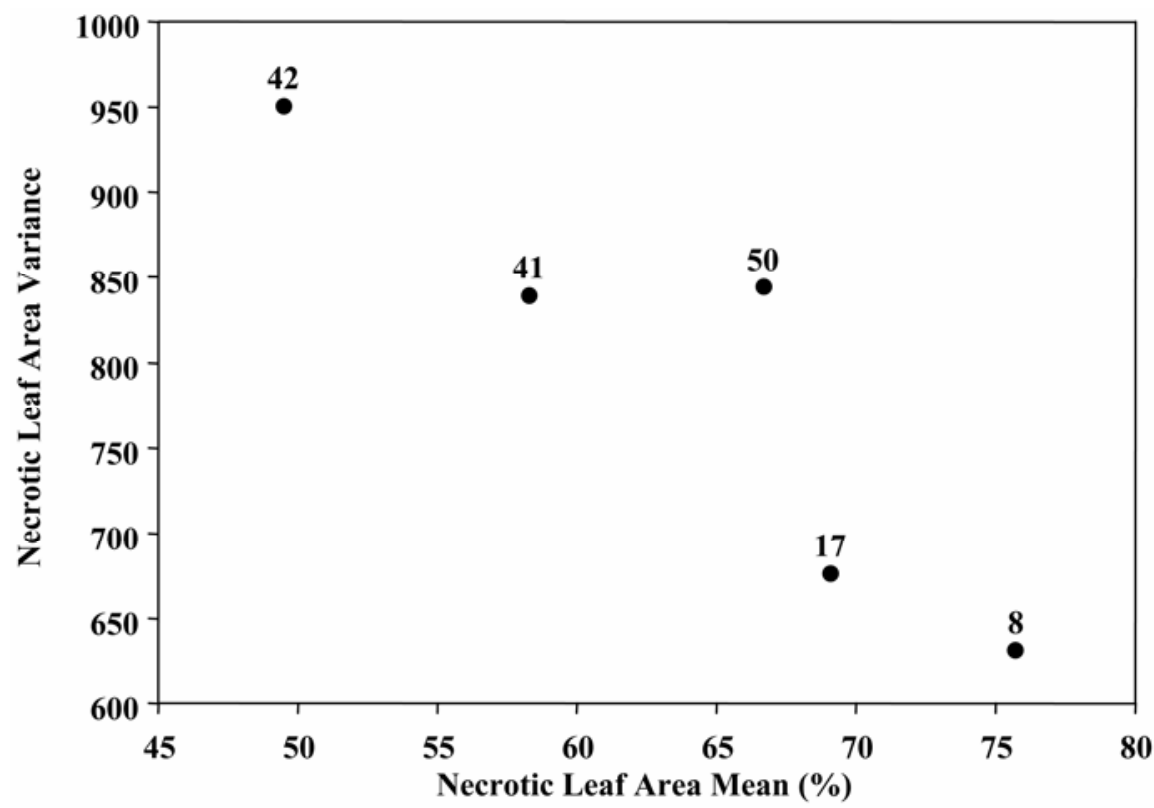

Fig. 1. Scatter plot of necrotic area means versus variance for five isolates of Septoria musiva screened in the leaf disk assay. 
leaf area was smallest on leaf disks from DN34 and largest on those from NE299 and Jackii4 (Table 4). There were no significant clone $\times$ isolate interactions $(P=0.186)$.

In vitro culture growth assay. Isolate 17 had significantly larger mean area growth in vitro than isolates 41 and 8 (Table 5). Isolates 41 and 8 were similar in mean growth, and isolates 17,50 , and 42 were similar in mean growth (Table 5).

Comparisons of assay means among isolates. Experiment 1 canker area means were positively correlated with isolate mean growth in vitro $(r=0.625)$, but were not correlated with experiment 2 canker area means $(r=-0.305)$ nor necrotic leaf area means $(r=-0.049)$ (Table 6). However, experiment 2 canker area means were negatively correlated with necrotic leaf area means $(r=-0.907)$ (Table 6). Experiment 2 canker area means were not correlated with mean growth in vitro ( $r=$ -0.283 ) (Table 6). Mean growth in vitro and necrotic leaf area means were not correlated $(r=0.178)$ (Table 6).

Comparisons of assay means among clones. Necrotic leaf area means were positively correlated with canker area means in experiment $1(r=0.775)$ and experiment $2(r=0.606)$, and canker area means in experiments 1 and 2 were positively correlated $(r=0.725)$ (Table 7).

Relationships of aggressiveness and variance among clones. Isolates 42, 41, and 50 revealed the largest amount of variance in necrotic leaf area among clones in the leaf disk assay (Fig. 1). In the stem assay experiments, isolates 50 and 17 revealed the greatest amount of variance in stem canker area among clones (Fig. 2).

RAPD analyses. The five primers generated a total of 126 amplified DNA fragments. Each isolate had a unique RAPD profile; however, ANOVA did not reveal significant differences among isolates $(P=$ 0.067 ) (Table 8$)$. For each marker, the frequency of band present $(p)$ ranged from 0.02 to 0.98 , the frequency of band absent $(q)$ ranged from 0.48 to 0.98 , and genetic diversity at polymorphic markers $(h)$ varied from 0.04 to its maximum of 0.50 . Mean genetic diversity over all RAPD markers $(H)$ was 0.16 . One fragment $(1,636 \mathrm{bp})$ produced with primer OPF-15 was present in all but one of the 52 isolates of S. musiva.

The genetic relatedness among isolates of S. musiva was $\geq 80 \%$ (Fig. 3). However, molecular genetic distance among isolates was not related to host clone $(P=0.602)$, clonal parentage $(P=0.886)$, section of Populus $(P=0.526)$, collection city $(P=$ $0.740)$ or state $(P=0.307)$, month $(P=$ $0.704)$ or year $(P=0.760)$ of collection, and levels of previously determined field canker resistance of the host clones $(P=0.258)$.

\section{DISCUSSION}

The $\geq 80 \%$ genetic similarity among the 52 isolates suggests a high degree of relatedness, although no two isolates were found to be identical. RAPD genotypes of $S$. musiva were unrelated to isolate collection variables such as host parentage and the level of disease resistance, and geographic location and date of isolate collection. The absence of relationships may indicate that there is no specific adaptation of $S$. musiva to poplar cultivars grown within the same geographic region or among the same clones.

Two isolates that were collected from the same host at the same time (isolates 41 and 42) were found to be similar genotypes (Fig. 3). Although they were similar in growth in vitro (Table 5), 41 and 42 were dissimilar in the stem canker and leaf disk assays (Tables 3 and 4). In addition, results of the leaf disk and the in vitro growth assays were not correlated among isolates (Table 6). The results of the leaf disk assay and stem canker experiment 2 were highly correlated among isolates (Table 6). However, the results of the leaf disk assay and stem canker experiment 1 were not correlated (Table 6). So, it may not always be effective to screen leaf tissue for disease resistance with isolates that were used to identify clones resistant to stem disease. In addition, potential clone $x$ isolate interactions, as were detected in experiment 2 of the stem canker assay, may complicate screening results. However, the strongly positive correlations in across-isolate stem canker and leaf disk assay means confirmed that the assays are reliable tools for discriminating among hybrid poplar clones for level of disease resistance. Genotype $\times$ environment interactions should be considered when choosing isolates for disease resistance screening. The interactions may result from a less favorable environment for disease development or reduced aggressiveness of the pathogen population at some locations (1). All these factors must be taken into account when isolates and assay methods are selected for disease resistance screening.

The effectiveness of disease resistance screening can be improved by considering and adjusting for the variability among isolates, among clones, and among screening methods. Our results indicate that it may not be most effective to select isolates for screening based only on their level of aggressiveness. It may be more useful to choose isolates that can allow the largest discrimination between levels of disease resistance among clones (1). For example, isolates that incur a relatively small acrossclone variance in assay results are the least able to discriminate between levels of disease resistance among clones. Isolate 42 revealed the greatest across-clone variance in necrotic leaf area in the leaf disk assay (Fig. 1), and this isolate may be more useful than the others in further screening of poplar leaf tissue. Isolate 50 may be more useful than the other isolates in screening for canker resistance, as this isolate revealed the greatest across-clone variance in

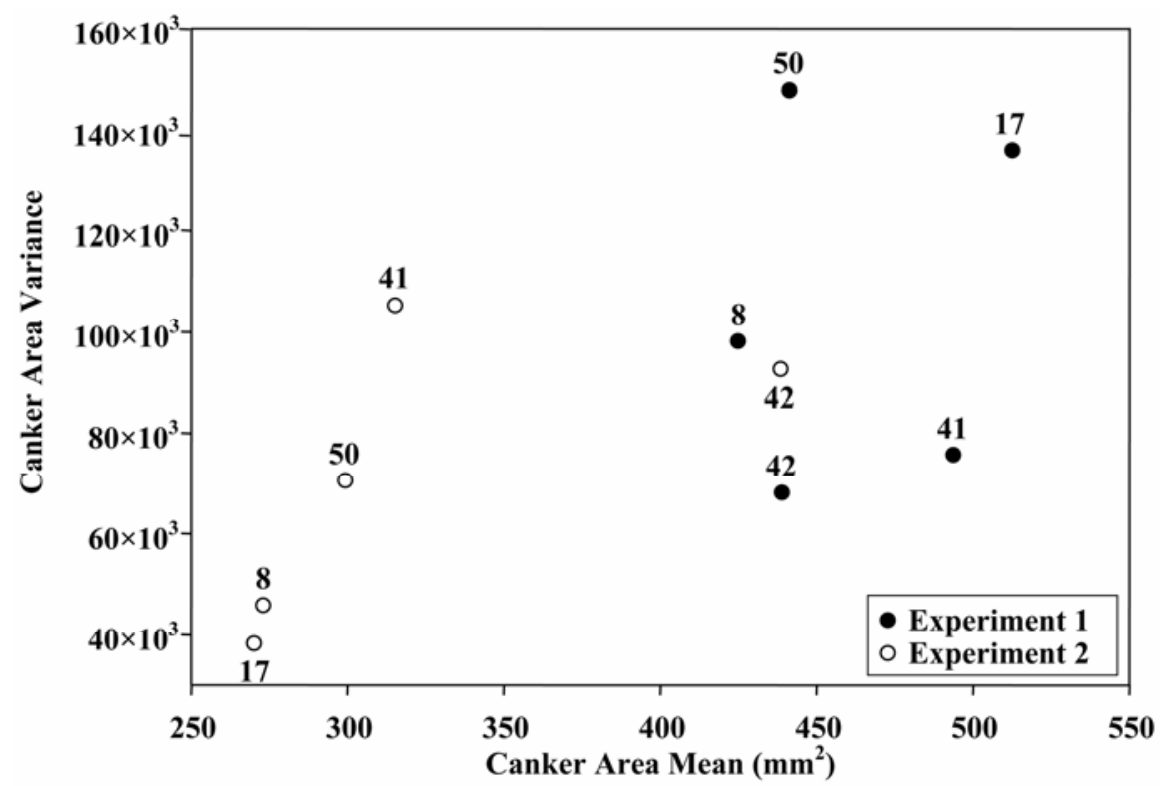

Fig. 2. Scatter plot of canker area means versus variance for five isolates of Septoria musiva screened in the stem canker assay.

Table 8. Analysis of variance results of random amplified polymorphic DNA (RAPD) marker presence and absence among isolates of Septoria musiva

\begin{tabular}{lccccc}
\hline Source & df & Sum of squares & Mean square & $\boldsymbol{F}$ & $\boldsymbol{P}$ value \\
\hline Model & 51 & 6.696429 & 0.131303 & 1.312 & 0.067686 \\
Error & 6,500 & 650.5 & 0.100077 & & \\
Corrected total & 6,551 & 657.1964 & & & \\
\hline
\end{tabular}




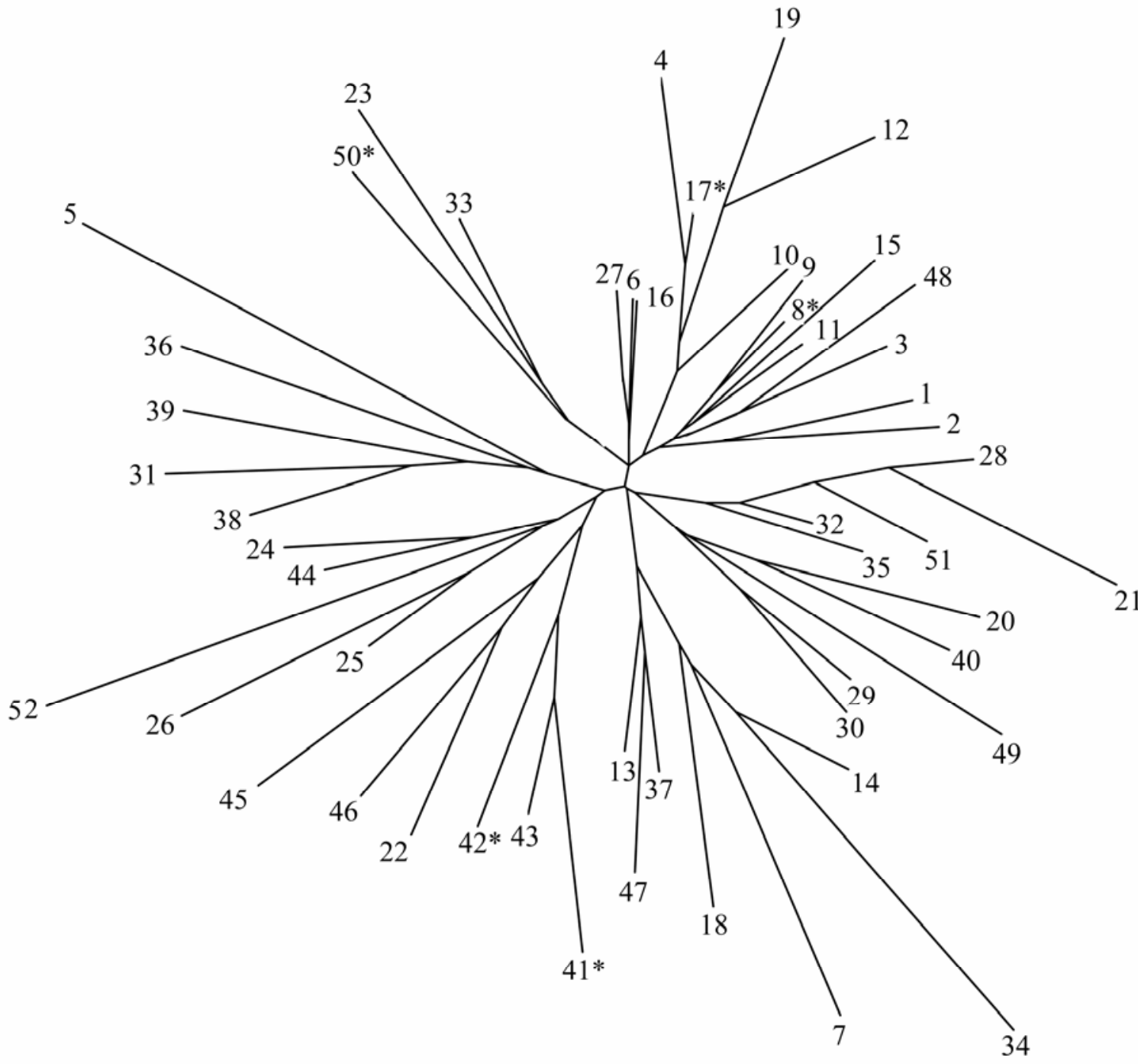

0.1

\section{Genetic Distance}

Fig. 3. Unrooted phyllogram from phenetic analysis of random amplified polymorphic DNA (RAPD) marker data from 52 isolates of Septoria musiva. Codes followed by an asterisk are isolates of $S$. musiva that were used in leaf disk, stem canker, and in vitro growth assays.

stem canker area (Fig. 2). Overall, two criteria should be established for isolates under consideration for screening purposes. In preliminary assays to select isolates, those chosen should be aggressive and should reveal the greatest across-clone variance in assay results to maximize the discrimination between levels of disease resistance of clones in screening trials.

\section{ACKNOWLEDGMENTS}

We thank Glenn Furnier for his guidance in the molecular genetic methodology, Shawn Bernick for assistance with phylogenetic analyses of the RAPD marker data, and two anonymous manuscript reviewers who made many helpful suggestions. The research was partially supported by the U.S. Department of Energy Biofuels Feedstock Development Program, interagency agreement DE-A105-950R22434.

\section{LITERATURE CITED}

1. Carson, M. L., Goodman, M. M., and Williamson, S. M. 2002. Variation in aggressiveness among isolates of Cercospora from maize as a potential cause of genotype-environment interaction in gray leaf spot trials. Plant Dis. 86:1089-1093.

2. Goodwin, D. C., and Lee, S. B. 1993. Microwave miniprep of total genomic DNA from fungi, plants, protists and animals. Biotechniques 15:441-444.

3. Griffin, D. H., Ehrenshaft, M., and Manion, P. D. 1980. Host-selective toxins of Hypoxylon mammatum for Populus tremuloides. Pages 209-214 in: Proc. Joint Sympos. Resistance Mechanisms Poplar Dis. 1-5 September 1980, Kornik, Poland.

4. Krupinsky, J. M. 1989. Variability in Septoria musiva in aggressiveness. Phytopathology 79:413-416.

5. Mottet, M., Bussieres, G., and Vallee, G. 1991. Test precoce pour l'evaluation de la sensibilite de peupliers hybrides au chancre septorien. For. Chronicle 67:411-415.

6. Nei, M. 1987. Molecular evolutionary genetics. Columbia University Press, New York.

7. Netzer, D. A., Tolsted, D. N., Ostry, M. E., Isebrands, J. G., Riemenschneider, D. E., and
Ward, K. T. 2002. Growth, yield, and disease resistance of 7- to 12-year-old poplar clones in the north central United States. U.S. Dep. Agric. For. Serv., N. Cent. Res. Stn. Gen. Tech. Rep. NC-229.

8. Newcombe, G., Chastagner, G. A, Callan, B E., and Ostry, M. E. 1995. An epidemic of Septoria leaf spot on Populus trichocarpa in the Pacific Northwest in 1993. Plant Dis. 79:212.

9. Ostry, M. E. 1987. Biology of Septoria musiva and Marssonina brunnea in hybrid Populus plantations and control of Septoria canker in nurseries. Eur. J. For. Pathol. 17:158-165.

10. Ostry, M. E., McRoberts, R. E., Ward, K. T., and Resendez, R. 1988. Screening hybrid poplars in vitro for resistance to leaf spot caused by Septoria musiva. Plant Dis. 72:497-499.

11. Ward, K. T., Ostry, M. E., and Furnier, G. R. 1994. Morphological and molecular genetic variation among isolates of Septoria musiva. (Abstr.) Phytopathology 84:1145.

12. Waterman, A. M. 1954. Septoria canker of poplars in the United States. U.S. Dep. Agric. Circ. No. 947. 